\title{
Information and Communication Technology and Enhancement of Agricultural Extension Services in the New Millennium
}

\author{
Ephraim A. Orikpe and Gloria O. Orikpe \\ Department of Agricultural Education \\ Federal College of Education (Technical), Umunze \\ Anambra State, Nigeria
}

\section{Doi:10.5901/jesr.2013.v3n4p155}

\begin{abstract}
The ratio of extension agents to farmer in Nigeria is very high. More so, most of the agents depend on traditional means of communication to send across time bound agricultural information and research findings to farmers. This is no longer effective in the present dispensation if the farmers must achieve food sufficiency for the nation. This paper therefore, examined the usefulness of information and communication technology in the enhancement of agricultural extension services in Nigeria. It equally looked at the rationale for the use of ICT in agricultural extension services. Some useful recommendations were made among which are that government should embark on aggressive development of rural areas ensuring that electricity supply is regular, the Ministry of Agriculture and ADP should work cooperatively to recruit and deploy more qualified and ICT literate extension agents and the Ministry of Agriculture should invest in training the in-service extension agents and the farmers on usability of ICTs for information dissemination and retrieval.
\end{abstract}

\section{Introduction}

Information and communication technology, according to Unagha (2006) is an omnibus term that encompasses computer and telecommunications technology. It is any technology that is used in producing, organizing and distributing information. Wirsiy and Shafack (2002) see it as a broad based term that encompasses the gathering (acquisition), organization (packaging), storage and retrieval (dissemination) of information that can be in textual or numeric (books and documents), pictorial and vocal forms (audio-visual), using combination of all the above (multimedia) including computers and telecommunications (telephones). There is no gain saying the fact that information and communication technologies are the nervous systems of any contemporary society. It has led to a lot of achievements and innovations in different sectors of the economy including agriculture.

An effective agricultural extension depends on extension messages (information) reaching many farmers and farmers problems reaching extension staff quickly and regularly. The extension agent is the only extension worker who teaches the production recommendations directly to farmers. Through him, therefore, it is expected that the farmer benefits from agricultural research with the ultimate target of raising his agricultural production efficiency and effectiveness. Unfortunately, in Nigeria today, extension agents still depend heavily on traditional extension methods of communication. This is no longer effective for the time bound research discoveries and the high farmer extension agent ratio in the new millennium. 


\section{Rationale for the use of ICT in Agricultural Extension Services}

The extent to which the extension agent effectively carry out the all important function of communicating with the farmers leaves much to desired. This is in view of the fact that the ratio of extension agents to farmers is very low. The Anamabra State Agricultural Development Project (ASADEP, 1987) noted that each extension agent is expected to cover about 800 to 1, 200 farm families. Similarly, Ekong (2005) opined that it is ideally expected that farmer-extension agents ratio in the country should be 750 farm families or less to one full-time extension agent. He however regretted that as at the year 2000, the ratio remained at an average of 2, 500:1.

With the above painted scenario, it is obvious that the extension agent cannot effectively cover all farm families forth nightly, particularly with the use of traditional extension methods. Constraining factors such as distance, bad roads, poor communication capacity, dialectical problems, poor transportation facilities and inadequate funding pose great problems to effective communication of information to farmers. It is clear, therefore, that the traditional mode of transmitting research findings to farmers through face to face encounter only, no longer adequately handles time bound information that should circulate within the farming population. Innovative changes brought into the field of agriculture scarcely reach the rural farmers who are the major stakeholders as far as food production in this country is concerned. Uwaka (1983) regretted that many new ideas and improved practices advocated by extension officers are difficult for the African farm families to obtain. Similarly, Chadwick (2003) opined that agricultural development in Nigeria has been hampered by how level of agricultural information exchange. By implication, the outstanding problem lies in the fact that current research findings do not reach the farmers as and when due.

Effective communication reflects a situation in which a skillful communicator duely sends a useful message through the proper channel to the appropriate audience who responds as desired (Unamma, Nwosu and Onwudike, 2005). However, the emerging challenge to farmers in this new millennium is how to cope with information explosion and global trend in agro-technology. There is the need therefore, for inter-related and communicatively linked systems to diffuse information and technological innovations to farm families. The role of research as a source of technical knowledge for the development of agriculture is critically vital but as observed by Nwachukwu (2003), there is a dire need to transfer technology from the technology developers to the technology utilizers through effective communication technology. Herein lies the rationale for utilizing ICTs in agricultural extension services particularly in this new millennium.

\section{Using ICT to Enhance Agricultural Extension Services}

Adivi (1996) described modern technology as a science that deals with all the creation, transmission and application of knowledge designed to bring about planned changes in the behavioural complex of people with a view to helping them live better life through learning new ways of improving their vocation, enterprises and institutions. The use of ICT has arisen because of the need to cope with information explosion in various sectors including agriculture. In order to keep pace with disseminating the increasing number of information or discoveries from different research institutes, computers and telecommunications must be utilized to handle information processing and dissemination with greater speed and accuracy than manual processing and delivery through extension agents. We live in a rapidly changing world marked by increasing emphasis on information.

Broadly speaking, information refers to data and knowledge of related inputs and outputs of a system including ways in which these are transformed within the system (Ozagediz and Ostem, 1998). Communication includes all the methods and mechanisms enabling access to information products and their circulation between the various kinds of actors in its administration. Since information is the major tool for extension service, communication or the dissemination of 
information about agricultural operations and productions play a vital role in sustaining an effective agricultural extension service. Hence, Nwachuckwu (2003) averred that agricultural communication is the effective transfer of agricultural technological innovation from technology developers (e.g research institutes, universities, private organization, etc) to the technology utilizers (e.g the farmers). For an agricultural information to be useful, the extension agents have to map out the information and communication needs of farmers within their agricultural and socio-economic systems and help key elements in that system to find information they need, when they need it, in accessible terms and language, at prices that are realistic at the given available resources and development objectives. Effective communication of agricultural information to farmers is of critical value in achieving optimum efficiency in agricultural extension administration and practice in Nigeria.

Various forms of ICT devices abound in the country today. It is expected that these available forms of ICT devices should be effectively utilized by extension agents to enhance agriculture extension services. The available ICT facilities are grouped into broadcast technology, print technology and telecommunication/computer technology (Okon, 2005). Broadcast technology refers to the broadcast media such as radio, projectors, media van etc. Print technology includes print media such as newspapers, magazines, bulletins, posters, calenders of work, newsletters, leaflets, pamphlets etc. The telecommunication/computer based technologies include telephones, global system and mobile system, computers, facsimile (fax), electronic mail service (e-mail), CDROM, internet etc.

Radio communication is obviously one of the fastest, most powerful and in most countries the most popular means of communication with the rural farmers. It defeats obstacles faced by extension workers (Omosa, 2001). Various studies have indicated that as far as agricultural extension work is involved, radio has proved to be one of the most vital and most effective means of disseminating agricultural information and innovations in the developing societies where the greater majority of the rural farmers are illiterates. For instance, Mundy and Sultan (2001) state that in Mali, the establishment of community radio stations within a radius of $100 \mathrm{~km}$ enables extension officers to reach about half a million farmers in their local languages. The use of local dialect in area of reception encourages addressing of issues of local interest thus breaking literacy barrier created in print media. Moreso, radio is adaptable to local conditions as it can be used without electricity and it is easily affordable.

The television set combines sight and sound thereby increasing the possibility of grasping and retaining the subject matter presented. It provides its audience with a sense of participation, personal access and reality which approximates face to face contact. Projectors can be used to disseminate information using motion pictures, slides, transparencies etc, by extension officers to demonstrate different farming techniques. Telephone or GSM can be used to communicate information between extension agents and farmers or react to questions relating to farm problems with the advantage of possibility of feedback.

The increase in accessibility to computers nation wide and new computer software packages now makes it possible to use the computer as a means for communication, information storage and retrieval. Computers should not only be used for communication in Agricultural Development Projects (ADPs), but should also be used for graphic work coupled with production of images that serve as teaching aids for the farmers. With proper networking, a computer user at one ADP location can communicate with other ADP officers with the use of modem or telephone lines bringing information nearer to the farmers.

E-mail is the most commonly used new ICT facility and has caused a cultural revolution in the way individuals and organizations interact in terms of time, cost and distance. Research institutes, NGOs and government sectors make use of their e-mail facility to send messages to other sectors and head offices, request for information, set up meetings, negotiate contracts, submit reports and keep in touch with people within and outside the country. This could be employed in agricultural 
extension services if the enabling environment is provided. These and other ICT facilities could be employed in agricultural extension services to ensure effective service delivery.

\section{Conclusion}

World Bank (1990) recommended that extension should forge new links and create networks for sharing knowledge and experience. Hence, there is need for the application of information and communication technologies in information dissemination to farmers. Food and Agricultural Organization (FAO, 1993) opines that information technologies bring new information services to rural areas over which farmers as beneficiaries will have much greater control than other information channels.

The use of information and communication Technologies has arisen because of the need to cope with information explosion in various sectors including agriculture. In order to keep pace with disseminating the increasing number of discoveries from various research institutes, computers and telecommunications should be utilized as they ensure greater speed and accuracy than manual delivery through extension agents.

It is hoped that with proper harnessing of the potentials of ICTs by extension agents, Nigerian agriculture will be transformed such that the rural poor will have access to global knowledge system. When Nigerian agriculture has been transformed the problem of food scarcity would have been solved and the standard of living improved for all.

Extension officers are the ones that provide proper management of information, communication and knowledge that allow farmers to make better management decisions that will improve their long-term livelihoods and enhance global linkage. However, for ICTs to successfully facilitate extension officers' role of information dissemination, such enabling variables as accessibility, capacity of use and other constraining variables have to be taken into consideration. The results of increased available knowledge that ICTs facilitate on the farmers will include higher income, improved efficiency in product harvesting, processing and storage, higher yields ensuring improved food security, improved livelihoods etc.

\section{Recommendations}

1. As a matter of priority, government should embark on aggressive development of rural areas, ensuring that electricity supply is regular and helping to subsidize ICTs for farmers.

2. All service providers must as a matter of necessity strengthen their telecommunication network in Nigeria with particular emphasis on the rural areas where the farmers and extension agents are located.

3. National Communication Commission (NCC) should closely monitor the activities of the service providers to ensure that users are not exploited unnecessarily and that efficient services are provided.

4. Ministry of Agriculture and ADP should ensure the airing of agricultural programmes on radio and television stations at such times that they will be useful to the farmers.

5. The government should establish television viewing centres in rural areas where agricultural programmes can be broadcast and viewed by rural farmers.

6. Government should step up effort at ensuring that the current drive at maintaining steady power supply is sustained.

7. The Ministry of Agriculture and ADP should work cooperatively to recruit and deploy more qualified and ICT literate extension agents.

8. The Ministry of Agriculture should update the extension communication facilities available to the extension agents with more modern information and communication technologies. 
9. The Ministry of Agriculture should invest in training the extension agents in service and the farmers on usability of ICTS for information dissemination and retrieval. Such training could come inform of seminars, conferences, workshops or train the trainers courses.

\section{References}

Adivi, A.R. (1996). Extension Education, Sree Lakashmic: Bapatla Press.

Anambra State Agricultural Development Project (1987). The Role and Functions of Extension Agents. A Paper presented at the Orientation course for new staff in Nsukka Zone, $8^{\text {th }}$ Dec.

Chadwick, B.P. (2003). Knowledge Techniques for Sustainable Development: Future Directions in Agric and ICTs in USAID: USA: Winrock I nternational.

Ekong, E.E. (2003). Rural Sociology: An Introduction and Analysis of Rural Nigeria (2 ${ }^{\text {nd }}$ ed.) Uyo, Nigeria: Dove Edu. Publishers.

FAO/Word Bank (2000). Agricultural knowledge and Information System: Strategic Vision and Principles. Rome: FAO/WB Publication.

Nwachukwu, I. (2003). Agricultural Communication: Principles and Practice. Umuahia: Lamb House Publishers.

Okon, D.P. (2005). Evaluation of the Access and Uses of ICTs among Public and Private Extension Officers in the South - South Zone of Nigeria. Unpublished Ph.D. Thesis, Michael Okpara University of Agriculture, Umudike, Nigeria

Omosa, E. (2001). The use and Application of Various Communication Channels at Local and International Levels. Kenya: Forest Action Network.

Ozgediz, S. and Osten, A.V. (1998). Information Policy in the CGIAR. In: New International Technologies in Agriculture. Quarterly Bulletin of the International Technologies in Association with Agricultural Information Specialists. xxxix, (1-2).

Unagha, A. O. (2006). Towards an Information and Communication Technology Conscious Nigerian Society. In Uhegbu, A.N. (Ed), the Research librarian: Journal of the Nigerian Library Association, Abia State Chapter, 1 (1).

Unamma, R.P.A; Nwosu, A .C. \& Onwudike, O.C. (2005). Effective Communication. Umuahia: Michael Okpara University of Agriculture Press.

Uwaka, C.T. (1983). The Role of Agriculture Education in the Social and Economic Development of Nigeria. Proceedings of Training Workshop of Agricultural Extension. April 26-28. National Root Crop Research Institute, Umudike.

Wirsiy, K.C. and Shafack, R.M (2002). The Impact of Information Technology on Information Dissemination. In Madu, E.C. \& Dirisu, M.B. (eds): Information Science and Technology for school Library in Africa. I badan: Evicoleman. Pp. 86-93.

World Bank (1990). Agricultural Extension in Africa. In Aruna, B. (ed) World Bank Division Paper, African Technical Development Series, Washington D.C. 
